\title{
The Crime Curve of Turkey: Does crime decrease with age?
}

\author{
Mehmet Akalın
}

\begin{abstract}
Age distribution of crime is one of the few issues in criminology that received sufficient attention in the West. Some scholars argued that this age distribution is adequately invariant over time, place and type of crime; whereas, others admit that this distribution differs over place and type of crime. Although age-crime curve looks similar in many ways, in fact, a slight difference has been recognized in most countries. This age-crime curve may also help out to focus more on the causes of criminality of specific age groups. Establishing this age distribution is also important because it may play a guiding role for law enforcement personnel and in constructing preventive programs. This article is written primarily to find out how age-crime curve looks like in Turkey. In doing this, prison statistics used here as the primary source.
\end{abstract}

Keywords: Age Distribution; Age-Crime Curve; Type of Crimes; Invariance; Causes of Crime.

\section{1-Introduction}

Aging and criminal activity relationship goes back to the early years of criminology. For instance, Quetelet (1831) found that the crime frequency tends to peak in adolescence or early adulthood and then decline with age (Ulmer and Steffensmeier, 2015, p.377). In fact, this pattern has not changed much since then. Hirschi and Gottfredson (1983) have further claimed that the age-crime relationship does not change across groups, societies and times (p.550). The claim of invariance in the age-crime relationship was contested soon after it was first articulated in 1983 and has tested in many ways in many countries (Greenberg, 1985; Steffensmeier, 1989).

Those studies have ended in with various results. Some have shown that the age-crime curve remains constant even though societies have undergone a long period of change and development. In other words, criminal behavior increases during the adolescence. This increase reaches to its peak during the middle late teenage years. The frequency of criminal behavior then begins to decline steeply at first and thereafter more steadily (Farrington, 1986, s. 192).

However, some scholars, challenging this simple fact, have argued that the age crime curve might differ among type of crime and from society to society. Besides, the causes of crime are agegraded and variable over the life cycle (Greenberg, 1985; Matza, 1964; Sampson and Laub, 1993; Shover, 1996; Steffensmeier et al. 1989). In addition, studies also indicate that some type of crimes peak at different ages (Soothiil et all, 2004).

This article was written to find out whether the age distribution of crime in Turkey is constant or not. Secondary purpose was to reveal whether the age-crime curve differs as the type of crime changes. Three different sources have been used in the study but the primary source was prison records.

\footnotetext{
${ }^{1}$ Ph.D., Turkish National Police, akalinmehmet1971@yahoo.com
} 


\section{2-Literature Review}

Although many studies have been conducted between the age and crime relations, the heated debate has started with the study of Hirschi and Gottfredson. In their study, Hirschi and Gottfredson (1983) have provided four age distributions of criminality from different countries in different time periods: England and Wales (1840), England (1908), Argentina (1960s) and United States (1970). To them, all four distributions were sufficient to suggest that little or nothing has changed over time. The shape or form of the distribution has remained virtually unchanged for about 150 years. Therefore, they have pointed out that the age-crime curve remained constant although a long period of change and development has taken place in a society. They have also emphasized that this issue was valid in different populations across different time periods and over a broad range of social conditions and the age distribution of crime is basically the same for different offenses. For most offenses in most societies, crime rates rise in the early teen years, peak during the mid to late teens and decline thereafter (p. 555-580).

The study on age-crime curve has continued thereafter. While some studies were supportive, majority of the studies were not. Those who found supportive results had focused mainly on the test of age-crime curve. For example, after reviewing evidences and examining data, Steffensmeier and his associates (1989) reached the conclusion that the age and many kinds of crime for various populations follow a similar pattern, characterized by a single peek occurring fairly early in the life cycle, usually in the late teens for most offenses, with steady declines thereafter (p. 825-826).

In addition, Eisner (2001) found that the commission of delinquent behavior followed a similar pattern in many different countries. He stated that the ages of 10 to 12 is the time for adolescents to increase their delinquency and 18 is the time when delinquency peaks for adolescents. Then, delinquency declines when adolescents reach 25 to 30 years (p. 203).

On the other hand, the majority of studies have indicated that the findings of Hirschi and Gottfredson were not totally true. Most scholars in this position have stated that the age distribution of crime is not constant. In response to the claim of Hirschi and Gottfredson, Greenberg (1985) noted that half of the Indian population is under 21; however, only a small portion of it $(3 \%)$ were arrested in 1980s. This was in fact a sharp contrast with the pattern in the United States (p. 1-21).

Tittle and Grasmick (1997) have pointed out that using official data might to some extent be misleading. Therefore, self-reports should be used to have more reliable outcomes. In their study, although minor theft, major theft, force and fraud basically conform to the curve of Hirschi and Gottfredson, tax cheating, which is a form of white-collar crime, has given different result. Tax cheating has increased through middle age and has declined thereafter (p. 321-322).

Laub and Sampson (2003) found significantly differing age curves and peak ages for property (younger age peak), violent (age peaks in the mid-20s), and drug/alcohol (peak involvement in the mid-30s) crime types (p. 311).

Tremblay and Nagin (2004) admitted that had early misbehavior and conduct problems taken into account, the age-crime curve would have peaked far earlier (p. 47). In addition to them, Soothill et al (2004) studied different offense categories and found that the age distribution of crime was not constant. They pointed out that the peak age for burglary was lower than 16 year; whereas, the peak age for fraud and forgery between 21 and 25 . Besides, the number of theft offenses far exceeds the number of murder or white-collar cases in any society (p. 401-418).

Besides, examining the homicide statistics of Japan, Ulmer and Steffensmeier (2015) have stated that the age curve for homicide in Japan have changed dramatically from 1960 to 1980 and 2000. The age-homicide curves for 1980 and 2000 are much flatter, with more gradual increases, far shorter peaks, and slower declines compared to 1960. In contrast to the recent U.S. pattern, none of the age-homicide curves peak in late adolescence or even in the early 20 s. Homicide peaked at 25 years of age in 1960 and around 35 in 1980 and 2000 (p. 385-386). 
Brief literature above indicates mixed results on the age distribution of crime. Therefore, it is plausible that the claim of Hirschi and Gottfredson has not gained strong ground in the agecrime curve. However, there is one thing that they are not wrong is the fact that adolescents commit more crime than any other age groups. In explaining this, Ulmer and Steffensmeier (2015) said that young people are more likely to be involved in some kind of violence such as street fight and gang violence but less opportunity for other crimes such as domestic violence. On the other hand, older people may have more opportunities for less visible criminal roles or they may commit some crimes that are less likely to be reported to the police (p.387).

The cause of criminality in adolescence years had been studied long before. Sheldon and Eleanor (1950) stated that the majority of delinquent behaviors were committed with delinquent companions. In addition, poor educational achievement and school failure were found to be more likely the cause of delinquent behaviors (p.42). In addition, it is well known that adolescence is the time when young people spend most of their time with their friends. Therefore, most of the learning processes, whether criminal or conforming, take place among peer groups. In this respect, Burgess and Akers (1966) indicated that this learning process is the result of social exchange in which the words, responses, presence and provides the setting for reinforcement (p. 135). A decade after Burgess and Akers; Elliott, Ageton and Huizinga (1978) have also founded that the most important proximate cause of delinquent behaviors is the strong bonding to delinquent peers.

In addition to peer groups, family is important predictor for delinquent behaviors among adolescents. Hirschi (1969) stated that the primary reason for adolescents to commit crime was the lack of close relations with their parents. In other words, adolescents who have close relations with their parents are less likely to be involved in delinquent behaviors. In saying this, Hirschi believed that the emotional bond between parent and adolescent was like a bridge that facilitates parental ideals and expectations pass on to adolescents. Whenever this emotional bond is weak, adolescents will not be able to develop adequate conscious or superego to conform the rules in society (p. 86). He further asserted that two thirds of adolescents, whose friends were picked up by the police, engaged in delinquent behavior; whereas, only one fourth of adolescents with no delinquent friends committed delinquent acts (p.135).

In order to explicate family-delinquency relations, Sampson and Laub (1993) proposed four factors that will increase the likelihood of delinquency: "erratic, threatening, and harsh/punitive discipline; low parental supervision; parental rejection, and weak emotional attachment." In testing their propositions, they found that parent's erratic/harsh punishment, low parental supervision, parental rejection, and weak emotional attachment are all correlated with delinquency (p. 65).

Another significant factor for adolescence delinquency is employment. The research on employment has established several basic empirical findings. First, the meaning of work and its implications for crime appear to change at some point during the transition to adulthood. The bivariate association between employment and law violation is generally positive for juveniles (Bachman and Schulenberg, 1993; Gottfredson and Hirschi, 1990; Mihalic and Elliott, 1997; Wright, Cullen and Williams, 1997), but negative for adults (Farrington et all, 1986; Sampson and Laub, 1990). Those in the invariance camp argue that people with good work habits would be less likely to commit crime in the first place than people with poor work habits, even in the absence of employment (Uggan, 2000).

Moffitt (1993) mentioned qualitatively distinct four types of persons. The first type of individuals is called Adolescence Limited (AL) who starts committing crime or antisocial behaviors at adolescence years and stop committing a few years later. Second type of individuals is called Life Course Persistent (LCP) offenders who start criminal career very early in life and continue in the following years. Low-Level Chronics (LLC) is similar to adolescence limited offenders in a way that they start offending career at early adolescence. However, they continue engaging in criminal behaviors through adulthood but at a low rate (Moffitt, 2003). Although the continuity of criminal behavior does not stop for some offenders, the type of criminal behavior 
changes across time. It is not reasonable to expect adults to commit similar crimes as they committed when they were children or adolescents (Moffitt, 1993).

The age distribution of crime is important for several aspects. One facet is that age is used to criticize social theories of crime causation. Another significant reason to study age is to provide the foundation for other theories. The last argument is to justify recent emphases on career criminals (Hirschi and Gottfredson, 1983, p. 552). It is expected from this brief explanation about the age distribution of crime to shed light on this study.

\section{3-The Situation in Turkey}

Before starting off establishing the age distribution of crime in Turkey, it is important to note that there are three different sources that may help out to complete such a study like this: Police, prison and court statistics. Crime statistics are retrieved from police; inmate statistics from prison and opened criminal cases from court records. The latest crime statistics go back to the year of 2006; whereas, court and prison statistics belong to the year of 2013. Since this study is based on the age-crime relation, the preponderance of statistics used in this article was taken from prison records. However, prison records do not reflect the overall crime statistics of Turkey. For example, police records show that 246,808 theft cases (vehicle theft, theft from house, theft from vehicle and premise) have taken place in 2006; whereas, only 6,603 people have been arrested as a result of theft in the same year. This result indicates that only 2,6\% of all theft offenders have been incarcerated. In a similar manner, 36,608 injury cases occurred in 2005 and 7,727 people have been arrested. These figures show that only $21 \%$ of injury offenders have been arrested. In other words, the offenders of person crimes are more likely to be admitted to prison than the offenders of theft crimes. Therefore, it should be kept in mind that the crime curve in this study might not reflect the actual curve.

All three sources indicate that the crime is soaring in Turkey with significant speed. According to the police records, the number of crime has increased dramatically during the last decade. The crime rate has significantly boosted after 2004. In fact, the major surge has seen in the year of 2006 with $61 \%$ increase as comparison to previous year. The number of offenses against property in police records was around 125,000 in 2000; whereas, the number of offenses against person was about 135,000. Perhaps, the year of 2000 was the only year that person crimes surpassed property crimes. After this year, offenses against property are committed more often than person offenses. In 2006, only six years after the first police records, the number of offenses against property rose to 463,834; while offenses against person rose to 321,676 (Sargin and Temurçin, 2011, s. 29-30).

Each year commits more and more people crime and enters more people prison. According to the criminal court records, 1,531,713 cases were opened in 2006. The number of property offenses has increased $270 \%$; whereas offenses against person have increased $138 \%$ since 2000 . This increase in fact has not stopped and has continued to rise in the following years. This figure has increased to $2,826,268$ in 2013 . The number of cases opened at court against property rose to 620,980 and offenses against person rose to 655,910 in the same year.

On the other hand, while the number of inmates in 2009 was around 75,000; it rose to 161,711 in 2013 . The prison population has increased $117 \%$ in four years. Besides, the number of received inmates is close to the number of released inmates in each year. The entrance and exit population is close on annual base.

In addition to all these, there is one last thing remained that needs to be explained before getting started. This study focused primarily on property and violent offenses. Property offenses include; theft, damage to property, fraud and extortion. Violent offenses, on the other hand, include; injury and murder.

Based on the prison records, the first graphic below shows the age-crime curve of Turkey. The blue line is for the year of 2006 and the red line is for 2013. This graphic covers all types of crimes. The first graphic clearly indicates that the age distribution of crime is not similar with the 
age distribution of crime as Hirschi and Gottfredson had mentioned in their study. The crime peaks around mid-thirties and declines sharply after then. This age crime curve also remains constant across different time periods. Although the rate of crime starts increasing at teenage years, but the real increase is seen during adult years and the age distribution of crime does not change over time.

Graphic 1: The age distribution of inmates in the years of 2006 and 2013.

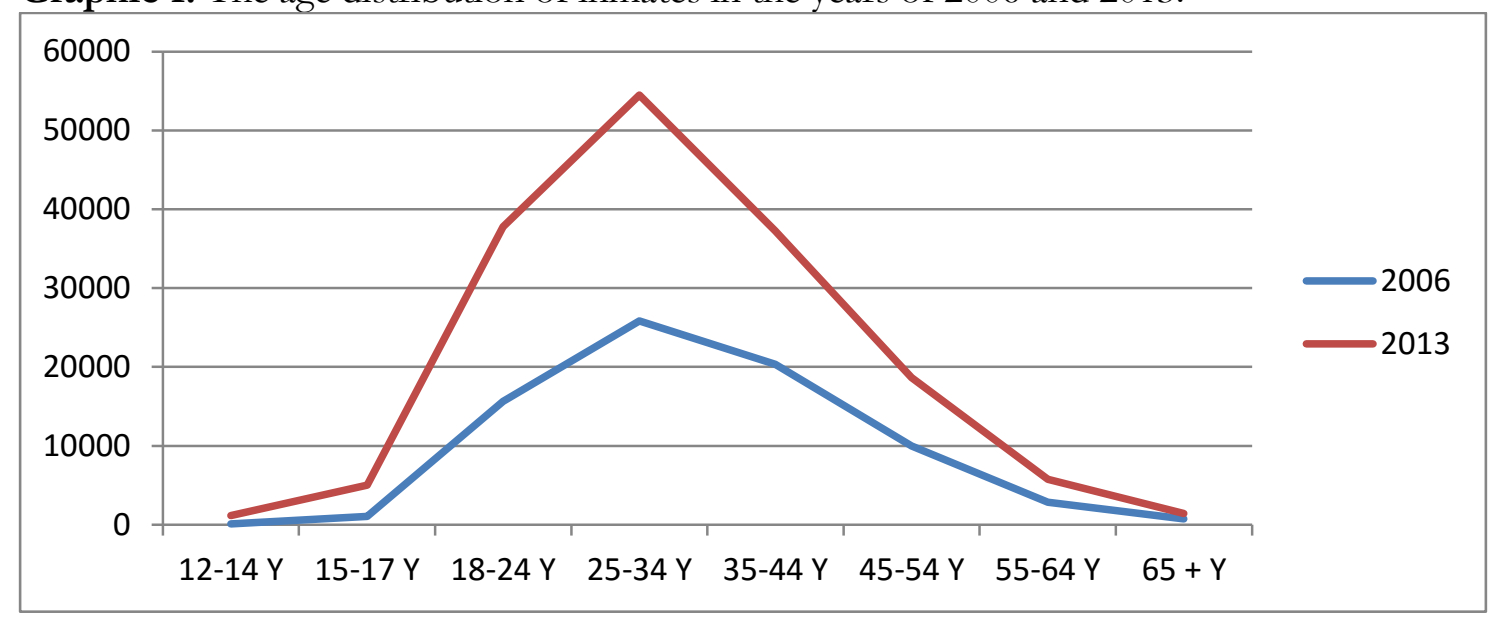

On the other hand, the second graphic indicates only the age distribution of inmates of property and violent offenses. The blue line is for property and the red line is for violent offenses. The total number of inmates for property offenses is 33,134; whereas, the number of inmates for violent offenses is 36,345 . The peak age for property offenses is about 20 , but violent offense age peaks at around 30 . The violent offenders exceed property offenders in prisons. Besides, this figure also shows that property crime offenders have committed crimes at earlier age than violent crime offenders.

Graphic 2: The age distribution of inmates on property and violent offenses in 2013

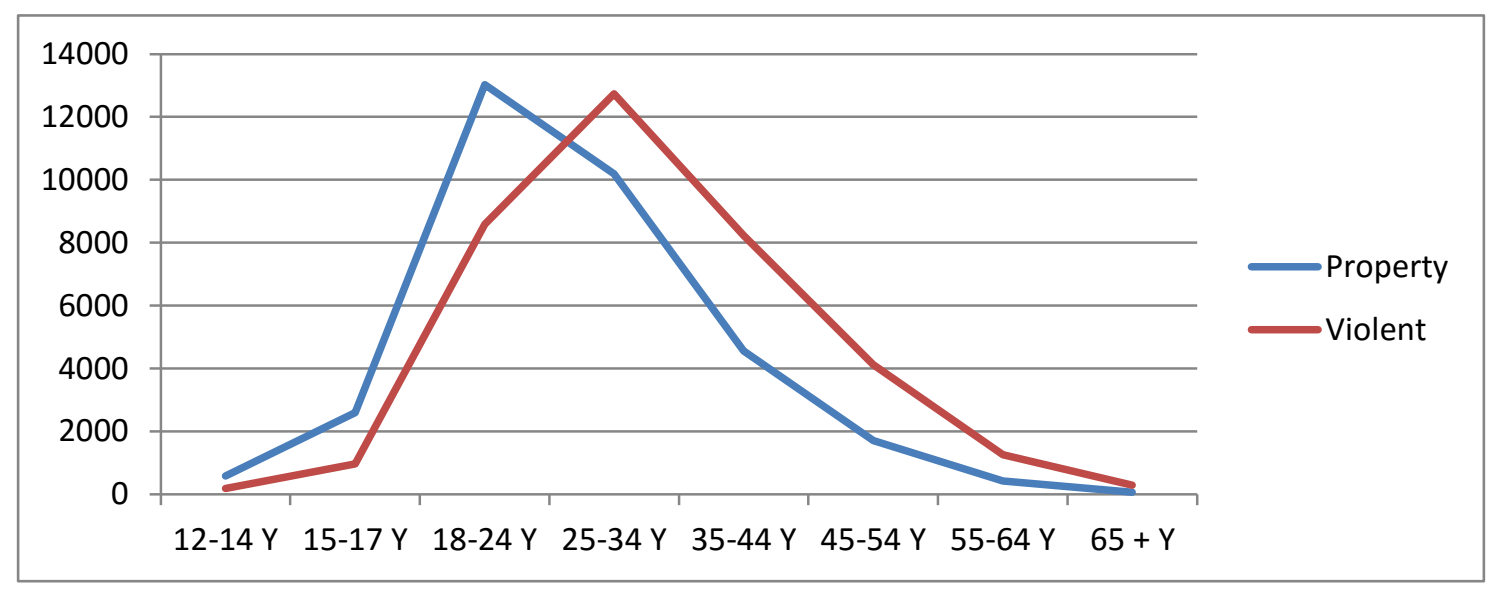

Another important issue here to be illuminated is whether the age crime curve follows a similar pattern for different crime types. As it is seen in the literature, although Hirschi and Gottfredson objected, the type of crime may play a role in the age distribution of crime. To find out whether type of crime matters, three different crime types are examined below. Red line is for theft, blue line is for murder and green line is for embezzlement crimes. 
Akalın, M. (2016). The Crime Curve of Turkey: Does crime decrease with age?. Journal of Human Sciences, 13(2), 27502757. doi:10.14687/jhs.v13i2.3854

Graphic 3: The age distribution of murder, theft and embezzlement in 2013.

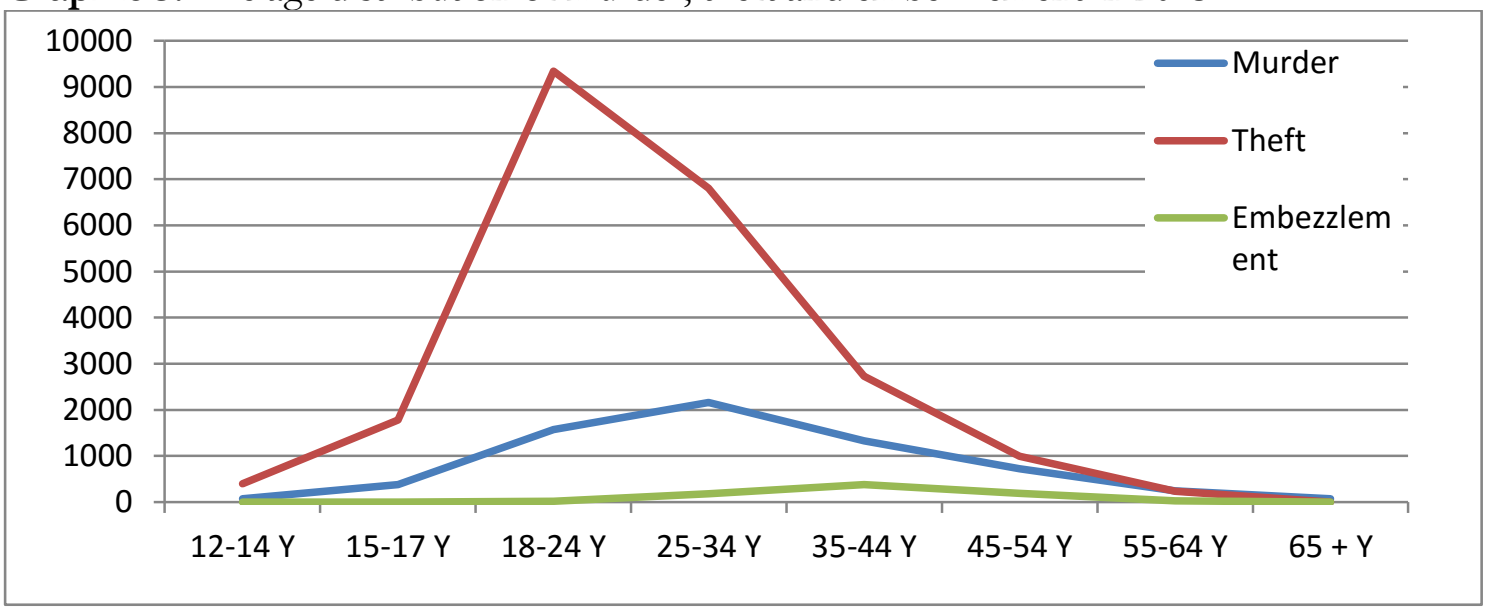

The third graphic shows that the type of crime matters. The age distribution of theft peaks earlier than other crime types. The peak age for theft is between 18 and 24. On the other hand, embezzlement, which is a white-collar crime, peaks toward the early years of forty. The murder crime peaks around 30s. The murder crime follows a similar pattern with general criminality in Turkey. This result explicitly supports the view that the crime curve differs with crime type.

Another important issue in criminal science is gender. Aside from type of crime, it is equally important to find out whether the age distribution of crime is different between male and females. To do this, total number of crime in 2013 and 2009 is studied. The result is shown in the graphic below. The blue line is for 2013 and the red line is for 2009 .

Graphic 4: The age distribution of female offenders in 2009 and 2013.

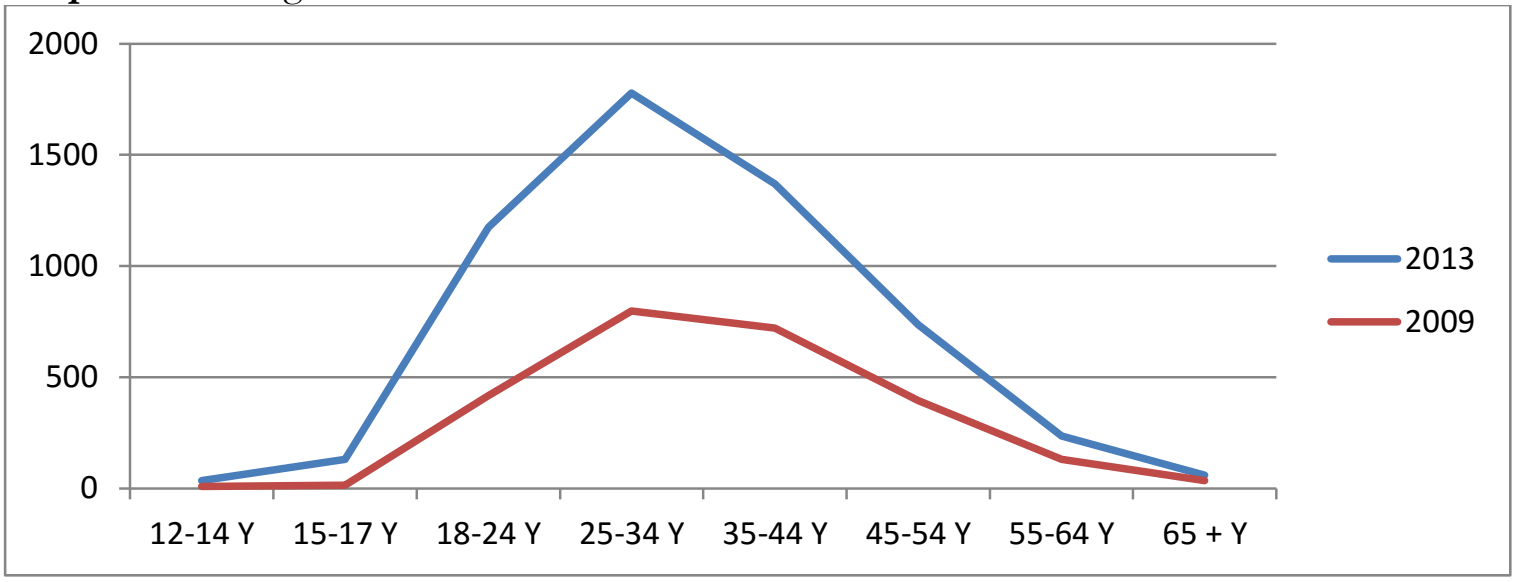

This graphic represents the age distribution of female offenders in the years of 2009 and 2013. The crime curve does not have much difference than the general crime curve of Turkey. The blue line clearly shows that the age peaks around 30s and then declines sharply. The red line also peaks at the age of 30s, but takes a little different path than the blue line for some years with slight decrease. Therefore, we can conclude that the crime curve has not intensely changed over time.

\section{4-Conclusion}

The court statistics show that the number of criminal cases opened at courts hit 3 million in Turkey in 2013. The number of property and violent offenses is very close 620,980 cases and 655,910 cases respectively. However, the number of property offense inmates is 33,206 and violent offense inmates are 36,352. These numbers indicate that only 5,3\% property offenders and 5,5\% 
violent offenders are sent to prison. The graphics above are generated from the prison statistics. Since actual crime statistics are not categorized by age, there is no strong reason to believe that young people commit less crime than adult in Turkey. However, the statistics of this small portion of inmates assert that the age-crime curve peaks around 30. This age, in fact, is far beyond the agecrime curve of Hirschi and Gottfredson. Then, it will be valid to say that the people of Turkey commit more crime in later years than the most people of Western countries.

According to the police statistics, in 2001 and in the five years that followed, property offenses exceed violent offenses in Turkey. However, the above graphics and court statistics indicate that violent crimes are committed more often than property crimes. Prison records show that violent crimes are committed more often by adult. By contrast, adolescents prefer to be involved in property crimes where monetary gains are more likely. This result supports the finding that the age distribution of crime differs in accordance with the type of crime. This finding also does not compatible with the viewpoints of Hirschi and Gottfredson.

Although females commit less crime, gender difference does not make any change in the age distribution of crime in Turkey. Female offenders are also incarcerated in late ages. But the real decline for females starts after the age of 40.

If the above findings are true, it will be conceivable to infer that people resort to violence in adult years. Because the age distribution of crime is the scope of this study, the cause of crime is not explicated here. However, it is, in fact, an important topic to find out why the people in Turkey commit crime in later years. Another significant issue here is that the people are committing more violent crimes than property crimes. This also may indicate that people are prone to violence in Turkey. These two separate issues, committing crimes in late ages and more violent crimes, need to be studied thoroughly to find out actual reasons.

\section{Reference}

Apel, R., Bushway, S., Brame, R., Haviland, A. M., Nagin, D. S., \& Paternoster, R. (2007), "Unpacking the relationship between adolescent employment and antisocial behavior: A matched samples comparison", Criminology, Vol. 45 (1), 67-97.

Bachman, G., Jerald and Schulenberg, John, (1993), "How Part-Time Work Intensity Relates to Drug Use, Problem Behavior, Time Use and Satisfaction Among High School Seniors: Are These Consequences or Merely Correlates?” Developmental Psychology, Vol. 29, pp. 220235.

Blumstein, Alfred, and Jacqueline Cohen, (1979), "Estimation of Individual Crime Rates from Arrest Records" Journal of Criminal Law and Criminology, 70 (4).

Burgess, L., Robert and Akers, L., Robert, (1966), "A Differential Association Reinforcement Theory of Criminal Behavior", Social Problems, Vol.14 (2), pp. 128-147.

Eisner, M. (2002), "Crime, Problem Drinking, and Drug Use: Patterns of Problem Behavior in Cross-National Perspective", Annals of the American Academy of Political and Social Sciences, Vol. 580, pp. 201-225.

Elliott, S., Delbert; Suzanne S. Ageton, and Huizinga, David (1978), "1977 Self-reported Delinquency Estimates by Sex, Race, Class, and Age", Mimeographed, Boulder, Colo.: Behavioral Research Institute.

Farrington, D, P., (1986), “Age and Crime” In Tonry, M. and Morris, N. (eds), Crime and Justice: An Annual Review of Research, Vol. 7, pp. 189-250.

Farrington, D. P., Bernard, Gallagher, Lynda, Morley, Raymond J. St. Ledger and Donald J. West, (1986), "Unemployment, School Leaving and Crime", British Journal of Criminology, Vol. 26, pp. 335-356.

Glueck, Sheldon and Glueck, Eleanor, (2003), "Unravelling Juvenile Delinquency", In Francis T. Cullen and Robert Agnew (eds), Criminological Theory: Past to Present-Essential Readings, Second Edition, Los Angeles, CA: Roxbury Publishing Company, pp. 36-47. 
Akalın, M. (2016). The Crime Curve of Turkey: Does crime decrease with age?. Journal of Human Sciences, 13(2), 27502757. doi:10.14687/jhs.v13i2.3854

Gottfredson, R. Michael and Travis, Hirschi, (1990), A General Theory of Crime, Stanford: Stanford University Press.

Greenberg, E. David, (1985), “Age, Crime and Social Explanation”, American Journal of Sociology, Vol. 91(1), pp. 1-21.

Hirschi, Travis, (1969), Causes of Delinquency, Berkeley and Los Angeles: University of California Press.

Hirschi, Travis and Gottfredson, Michael, (1983), "Age and the Explanation of Crime", American Journal of Sociology, Vol. 89, pp. 552-584.

Junger-Tas, J., Ribeaud D. and Cruyff, M. J. L., (2004), "Juvenile Delinquency and Gender", European Journal of Criminology, Vol. 1 (3), pp. 333-375.

Matza, David, (1964), Delinquency and Drift, New York: Wiley.

McVie, Susan, (2005), "Patterns of Deviance Underlying the Age-Crime Curve: The Long Term Evidence", Criminology and Criminal Justice, Vol. 7(25), pp. 1-15.

Mihalic, W., Sharon and Delbert, Elliott, (1997), "Short and Long Term Consequences of Adolescent Work", Youth and Society, Vol. 28, pp. 464-498.

Moffitt, T. E. (1993). Adolescence-Limited and Life-Course-Persistent Antisocial Behavior: A Developmental Taxonomy. Psychological Review, Vol. 100 (4), 674-701.

Laub, H., John and Sampson, J., Robert, (1993), "Life-Course Desisters? Trajectories of Crime Among Delinquent Boys Followed to Age 70", Criminology, Vol. 41(3), pp. 01-341.

Sargın, Sevil and Temurçin, Kadir, (2011), Türkiye'nin Suç Coğrafyası: Şehir Asayiş Suçları, Polis Akademisi Yayınları, Ankara.

Shover, N., (1996), Great Pretenders: Pursuits and Careers of Persistent Thieves, Boulder, CO: Westview.

Soothill, K., Ackerley, E. and Francis, B. (2004) "Profiles of Crime Recruitment", British Journal of Criminology, Vol. 44, pp. 401-418

Steffensmeier, J., Darrell, (1989), "On the Causes of White-Collar Crime: An Assessment of Hirschi and Gottfredson's Claims", Criminology, Vol. (27), pp. 345-358.

Steffensmeier, J., Darrell, Allan, E., Harer, M. and Streifel, C., (1989), "Age and the Distribution of Crime", American Journal of Sociology, Vol. 94, pp. 803-831.

Tremblay, R. and Nagin, D., (2004), "Physical Aggression During Early Childhood: Trajectories and Predictors", Pediatrics, Vol. 114(1), pp. 43-50.

Tanner, J., M (1978), Foetus into Man: Physical Growth from Conception to Maturity, Cambridge, Mass.: Harvard University Press.

Tittle, R., Charles and Grasmick, G., Harold, (1997), "Criminal Behavior and Age: A Test of Three Provocative Hypotheses", Journal of Criminal Law and Criminology, Vol. 88(1), pp. 309342.

Uggan, Christopher, (2000), "Work as a Turning Point in the Life Course of Criminals: A Duration Model of Age, Employment and Recidivism", American Sociological Review, Vol. 65(4), pp. 529-546.

Ulmer T. Jeffery and Steffensmeier, Darrell (2015), "The Age and Crime Relationship: Social

Variation, Social Explanations", In The Nurture versus Biosocial Debate in Criminology: On the Origins of Criminal Behavior and Criminality, Edited by: Kevin, M., Beaver; Barnes, J. C. and Boutwell, B., Brian.

Warr, Mark, (1998), "Life-Course Transitions and Desistance from Crime”, Criminology, Vol. 36, pp. 183-216.

Wright, P., John, Fransic, T., Cullen and Nicolas Williams, (1997), "Working While in School and Delinquent Involvement: Implications for Social Policy", Crime and Delinquency, Vol. 43, pp. 203-221. 